STRUČNI ČLANAK

\author{
Ana Galjak
}

\title{
GMO - HRANA BUDUĆNOSTI ILI FRANKENŠTAJN HRANA
}

\section{UvoD}

Genetski modifikovan organizam (GMO) je organizam - biljni ili životinjski - na kome su pri uzgoju metodom genetskog inženjeringa uneti geni nekog drugog organizma. ${ }^{1}$

Korišćenjem biotehnologije u poljoprivredi i medicini, naročito sredinom osamdesetih i početkom devedesetih godina, nastali su brojni genetski modifikovani (GM) organizmi i njihovi proizvodi. Genetski modifikovane biljke se proizvode u laboratorijama tako što se genetski materijal (samo gen ili čitava DNK) neke vrste ubacuje u DNK poznatih biljnih kultura. Na ovaj način unutrašnja genetska struktura modifikovane biljke zauvek je izmenjena, a željena osobina prenosi se na naredne generacije.

Sve veći broj zemalja, uključujući i evropske, donosi svoje propise o genetski modifikovanim organizmima i transgenim biljkama u cilju regulisanja svih pitanja stvaranja, gajenja i korišćenja genetski modifikovanih organizama. Istovremeno, multinacionalne kompanije, koje u potpunosti kontrolišu transgene biljke i kloniranje - „od ideje do komercijalizacije“ - okrivljene su za stvaranje "genetičkog imperijalizma“. Ovaj novi vid vladavine bogatih nad siromašnima posebno je usmeren ka nerazvijenim i siromašnim zemljama, koje neće imati drugog izbora, nego da se još više zaduže kupujući skupe proizvode savremene biotehnologije od bogatih zemalja. Uticaj genetski modifikovanih organizama može se negativno odraziti na životnu sredinu. Novi organizmi mogu se uspešno takmičiti sa divljim rođacima, uzrokujući promene u prirodi. Svi organizmi za čiji nastanak su korišćene tehnike savremene biotehnologije nazivaju se genetski modifikovani organizmi (genetically modified organisms - GMOs) ili živi modifikovani organizmi (living modified organisms - LMOs). Živi modifikovani organizmi uključuju niz prehrambenih biljaka koje su genetski modifikovane

\footnotetext{
* Studentkinja Pravnog fakulteta Univerziteta Union u Beogradu

1 http://www.ornl.gov/sci/techresources/Human_Genome/elsi/gmfood.shtml.
} 
u svrhu povećanja produktivnosti ili zbog povećane otpornosti na štetočine i bolesti. ${ }^{2}$

Molekularni biolozi su razvili mnoge enzime koji menjaju strukturu DNK u živim organizmima. Neki od tih enzima mogu razdvajati i spajati elemente DNK. Koristeći pojedine enzime, naučnici mogu da izdvoje pojedine gene iz DNK i izgrade prilagođen DNK korišćenjem tih gena. Dakle, u mogućnosti su da od postojećeg organizma stvore novi, laboratorijski organizam sa karakteristikama koje su želeli. Međutim, veliki problem nastaje zbog nemogućnosti tačnog predviđanja na koji način će se ponašati novonastala DNK, neizvesno je u kom će smeru ići dalja multiplikacija.

Autor će u ovom radu poći od definisanja pojma genetskih modifikacija, sa posebnim osvrtom na njihovo korišćenje u proizvodnji hrane i lekova. Takođe, predstaviće prednosti i mane manipulacije genetskim materijalom $\mathrm{u}$ proizvodnji svakodnevnih namirnica.

Autor će takođe skrenuti pažnju na uticaj biotehnoloških korporacija u naučnim istraživanjima iz oblasti bezbednosti hrane, zatim na zdravstvene aspekte konzumiranja genetski modifikovane hrane i njenog uticaja na životnu sredinu, a daće i kratak prikaz propisa iz ove oblasti na nivou EU i nacionalnog zakonodavstva.

\section{NASTANAK, RAZVOJ I POSLEDICE GENETSKI MODIFIKOVANIH ORGANIZAMA}

\section{GENETSKI MODIFIKOVANI ORGANIZMI - ISTORIJSKI RAZVOJ}

Ideja o mogućnosti prebacivanja gena iz jedne vrste u drugu rođena je u Honoluluu, novembra 1972. godine, na konferenciji o plazmidima (malim cirkularnim molekulima DNK koji se mogu naći u bakterijama). Ideja se zasnivala na upotrebi restrikcionih enzima, bakterijskih nukleaza koje sa velikom preciznošću prepoznaju i seku tačno određene nizove nukleotida $u$ molekulu DNK. U naredne dve godine, u seriji eksperimenata sprovedenih na Univerzitetu Stanford pokazano je da se ova metoda može primeniti za rekombinovanje gena ne samo iz nižih organizama (kao što su bakterije), već i kod viših organizama (kičmenjaka).

Naučnici koji su se bavili ovom problematikom odmah su shvatili potencijalni značaj ove tehnologije ali i moguće opasnosti koje mogu nastati iz njene nemarne primene. Zbog toga su naučnici u pismu naslovljenom Naci-

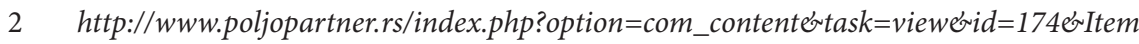
$i d=81$. 
onalnoj akademiji nauka (NAS), objavljenom i u časopisu Science, ${ }^{3}$ zahtevali da se stavi moratorijum na dalja istraživanja u ovoj oblasti. Na konferenciji u Asilomaru, Kalifornija, 1975. godine, 150 naučnika iz 30 zemalja postiglo je dogovor da se opšti moratorijum zameni kompleksnim nizom pravila za sprovođenje samo određenih tipova eksperimenata, dok su drugi eksperimenti sa rekombinovanim organizmima bili praktično zabranjeni, dok se ne prikupi dovoljno znanja. Zaključci sa ove konferencije, objavljeni 6. juna 1975. godine u časopisu Američke nacionalne akademije nauka, ${ }^{4}$ predstavljaju jedini slučaj u naučnoj zajednici kojom zajednica sama sebi nameće bezbednosnu i etičku regulativu.

Uprkos ovim preprekama, u narednim decenijama postali smo svedoci dramatičnog razvoja i komercijalizacije biotehnologije. Osamdesetih godina, razvoj biotehnologije ogleda se u produkciji humanih proteina u bakterijama, dok se kasnije prelazi na industriju hrane. Prva dva proizvoda rekombinantne DNK u industriji hrane pojavila su se na tržištu početkom devedesetih godina prošlog veka i odmah izazvala značajnije reakcije javnog mnjenja. Sredinom devedesetih, započelo se i sa komercijalnom proizvodnjom rekombinantne DNK tehnologijom izmenjenih organizama koji se kao takvi koriste u ljudskoj ishrani. Ovaj pristup zahtevao je da se u organizam domaćina, koji se želi genetski izmeniti, ubace najmanje dva nova gena - prvi, koji bi organizmu domaćina trebalo da pruži mogućnost sinteze određenog proteina, i drugi, koji bi trebalo da posluži kao selektabilni marker. Do danas je razvijen veliki broj biljnih sorti koje imaju sposobnost sinteze proteina koje u prirodi proizvodi neka druga vrsta, najčešće bakterijska, a koje upravo zahvaljujući tom proteinu stiču neku poželjnu osobinu (produžena svežina, otpornost na insekte, otpornost na određeni herbicid itd. $)^{5}$.

Velika američka kompanija „Monsanto“ bila je važan učesnik u stvaranju semena genetski modifikovanih žitarica i mahunarki. Dve ekonomski najznačajnije tehnologije proizvodnje genetski modifikovanog semena koje je razvio „Monsanto“ jesu:

- „tehnologija uvođenja Bacillus thurigiensis (Bt) gena, kojom bilike počinju da proizvode sopstvene pesticide i tako uništavaju štetočine koje ih napadaju i

- tehnologija uvođenja gena rezistencije na glifosat, kojom se stvaraju semena rezistentna na glifosat (Roundap), herbicid koji proizvodi 'Monsanto." 6

3 www.sciencemag.org/cgi/reprint/190/4212/324.pdf.

$4 h$ http://www.pnas.org/content/72/6.toc\#BiologicalSciencesBiochemistry.

5 Tarasjev, A., Stojković, O., Crnobrnja-Isailović, J., Etički aspekti istraživanja rada Nacionalnog saveta za biološku sigurnost - bioetika kod nas $i$ u svetu. Beograd 2006, SANU.

$6 \quad$ www.gmo.hr. 


\section{PREDNOSTI I MANE GENETSKI MODIFIKOVANIH ORGANIZAMA}

Upravo zato što genetske modifikacije donose mnoge prednosti, naučnici su se vredno bavili ovim pitanjem. Međutim, vremenom se pokazalo da su mane i opasnosti po čoveka i njegovu okolinu mnogo brojnije.

\subsection{Prednosti}

Zagovornici biotehnologije navode da nema dokaza da genetski modifikovani organizmi nepovoljnije deluju na životnu sredinu ili ispravnost namirnica u odnosu na njihove konvencionalno uzgajane kopije i ističu da su genetski modifikovane biljke veoma korisne za savremeni svet. Genetski modifikovane biljke sa genima Bt smanjuju potrebu za pesticidima (npr. genetski modifikovani krompir zahteva 40 odsto manje insekticida od krompira dobijenog tradicionalnim uzgajanjem). Genetski modifikovani kukuruz sadrži manje mikotoksina fumonizina. Genetski modifikovane biljke, budući otporne na herbicide, smanjuju potrebu za oranjem, što sprečava eroziju zemljišta. Takođe, povećanjem prinosa žitarica sprečava se krčenje šuma u potrazi za novim plodnim površinama i, što je najvažnije za zemlje u razvoju, ubrzava ekonomski razvoj i rešava problem gladi.

Prehrambeni proizvodi dobijeni biotehnologijom mogu popraviti kvalitet osnovi namirnice, npr. njen ukus i sastav. Za nerazvijene zemlje posebno je korisno gajenje pasulja otpornog na patogene, virus-rezistentne papaje, Bt pamuka, kao i pirinča obogaćenog vitaminom A. U skoroj budućnosti treba očekivati i krompir koji apsorbuje manje ulja pri prženju, kukuruz i soju sa povećanim sadržajem proteina, paradajz sa svežijim ukusom, kao i slađe jagode. ${ }^{7}$

Pri lečenju genetski uslovljenih bolesti, ksenotransplantaciji ili u proizvodnji lekova, dobrobit za čoveka koju donosi moderna biotehnologija i njena primena u medicini nemerljiv je. Već se dvadesetak godina genetskim inženjeringom proizvodi rekombinovani insulin koji je dijabetičarima omogućio kvalitetan život, a na isti način se proizvodi vakcina protiv hepatitisa B - virusne zarazne bolesti koja se prenosi krvlju, krvnim derivatima i polnim putem, od koje zahvaljujući vakcini imamo efikasnu zaštitu. Danas se već i brojni drugi preparati značajni za prevenciju i lečenje bolesti proizvode ovom tehnologijom - alfa 1 tripsin, glukagon, tireotropin, faktori zgrušavanja krvi, imunološki medijatori itd. $U$ daljem razvoju medicine, odnosno dijagnostike i prevencije, očekuje se prepoznavanje individualnih genetskih sklonosti za obolevanje od nekih bolesti. Dok je primena genetskog inženjeringa u medicini i farmaciji prihvaćena širom sveta, primena ove metode u proizvodnji

$7 \quad$ www.gmo-guidelines.info/. 
namirnica izazvala je velike reakcije javnosti i stručnih krugova zbog potencijalne opasnosti za okolinu i zdravlje ljudi. ${ }^{8}$

\subsection{Mane}

Na drugoj strani, za mnoge istraživače i javno mnjenje proizvodnja genetski modifikovane hrane (tzv. „frankenštajn“ hrane) predstavlja neprihvatljivo poigravanje sa prirodom.

Prirodni sadržaj cijanida u kasava krompiru štiti ga u zemljištu tako da on dobro napreduje. Ređim oranjem javljaju se ekološki i agronomski problemi: u proleće zemljište je hladnije i time se otežava razvoj biljke, a dolazi i do denitrifikacije azota u zemljištu. Takođe, proizvodnja Bt kukuruza nije dovela do očekivanog smanjenja upotrebe pesticida, a po nekima, genetski modifikovane biljke koje su rezistentne na herbicide čak mogu trostruko uvećati njihovu upotrebu. ${ }^{9}$

Postoje posledice koje bismo mogli nazvati opasnim, a to su: a) neprecizna tehnologija - genetičari prenose gene iz jednog organizma u drugi. Gen se može precizno uzeti iz DNK jednog organizma, ali je njegovo ubacivanje u DNK drugog organizma uglavnom slučajno. Kao posledica, postoji rizik da to može ugroziti funkcije drugih gena bitne za život tog organizma (Bergelson 1998); b) neželjeni efekti - genetski inženjering je kao izvođenje „operacije srca sa lopatom“. Naučnici nisu još proučili životne sisteme dovoljno kompletno da bi završili DNK operacije bez stvaranja mutanata koji mogu biti štetni za životnu okolinu i naše zdravlje. Oni eksperimentišu sa jako delikatnom i snažnom silom prirode, bez punog saznanja o reperkusijama (Washington Times 1997, The Village Voice 1998); c) rasprostranjene propasti useva - genetičari nastoje da profitiraju patentiranjem genetski modifikovanog semena. To znači da, kada zemljoradnik zasadi takvo seme, sve seme ima identičnu genetsku strukturu. Ako su gljive, virusi ili druge napasti razvijene toliko da mogu da napadnu takav usev, onda može doći do rasprostranjene propasti useva; d) pretnja našem ukupnom snabdevanju hranom - insekti, ptice i vetar mogu preneti genetski modifikovano seme u susedna polja i dalje. Polen iz modifikovanog bilja se može razmeniti sa genetski prirodnim usevima i

8 Zrinka Petrović, dr. med, mr. sc Krunoslav Capak, dr. med, Potencijalni zdravstveni rizici GMO-a, Hrvatski zavod za javno zdravstvo, 2006.

9 Dobar primer predstavlja Argentina, koja već deset godina uzgaja genetski modifikovanu soju. Te modifikacije bi trebalo da smanje potrebu za pesticidima, ali slučaj Argentine je dokazao sasvim suprotno. Povećala se potreba za pesticidima, sa otprilike 21 na 10 l, a pojedini korov je postao rezistentan, pa moraju da koriste zabranjene hemijske preparate ne bi li ga uništili.

Argentinu nazivaju zemljom soje. Čemu tolika produkcija kada niko neće da je uveze u svoju zemlju zbog genetskih modifikacija? (primedba A. G.) 
divljim rođacima. Svi usevi, organski i modifikovani, nezaštićeni su od zagađivanja razmenom polena. (Emberlin et al., 1999). ${ }^{10}$

\section{PROPISI EU}

Razvoj genetski modifikovanih organizama i apel naučnika da oni nose i opasnosti sa sobom, dovode do potrebe da se ova pojava i zakonski reguliše. Tako se u Evropskoj uniji, tada Evropskoj ekonomskoj zajednici (EEZ), donose prve direktive.

Najpre je, 23. aprila 1990. godine, doneta Direktiva 90/219/EEZ o ograničenoj upotrebi genetski modifikovanih mikroorganizama (GMM), ${ }^{11}$, koja nastoji da zaštiti ljudsko zdravlje i okolinu od negativnih uticaja koji mogu proisteći iz ograničene upotrebe (u strogo kontrolisanim uslovima) genetski modifikovanih mikroorganizama. Ona definiše i utvrđuje pravila za dopuštenu upotrebu genetski modifikovanih mikroorganizama u laboratorijama i industrijskim postrojenjima kroz detaljnu procenu rizika, prethodnog obaveštenja i dobijanje dozvole od strane nadležnih organa. Ova direktiva je 26. oktobra 1998. godine izmenjena i dopunjena Direktivom 98/81/EZ ${ }^{12}$ kojom se uređuje ograničena upotreba genetski modifikovanih organizama u istraživanju i u industriji. Ona se odnosi na rad sa npr. genetski modifikovanim virusima ili bakterijama koje se koriste u zatvorenim sistemima, tj. u sistemima u kojima je kontakt sa ljudima i okolinom izbegnut i to se odnosi na rad u laboratorijama.

Zatim je, 12. marta 2001. godine, doneta Direktiva 2001/18/EZ ${ }^{13}$ o namernom puštanju u okolinu genetski modifikovanih organizama. Cilj Direktive jeste da se sačuva zdravlje ljudi i okolina od rizika koji proizlaze iz namernog uvođenja genetski modifikovanih organizama u okolinu radi istraživanja i razvoja ili pak stavljanja u tržište proizvoda koji sadrže ili su napravljeni od genetski modifikovanih organizama. Direktiva takođe reguliše unutrašnje tržište Evropske unije tako da nijedna država ne može odbiti uvoz genetski modifikovanih proizvoda nakon što ga je već odobrila bilo koja država članica EU (osim ako postoje opravdani razlozi koji se tiču zaštite okoline ili zdravlja ljudi). Direktiva prihvata načelo predostrožnosti uspostavljajući sistem prethodne procene rizika, obaveštavanja pre uvoza i izdavanja dozvole od strane

10 www.aic.ba.

11 Council Directive 90/219/EEC of 23 April 1990 on the contained use of genetically modified micro-organisms (OJ No L 117 of 8. 5. 1990, p. 1); kompletan tekst Direktive nalazi se na internet strani http://ec.europa.eu/health/files/eudralex/vol-1/dir_1990_219/ dir_1990_219_en.pdf.

12 Council Directive 98/81/EC of 26 October 1998 amending Directive 90/219/EEC on the contained use of genetically modified micro-organisms .

13 Directive 2001/18/EC of the European Parliament and of the Council of 12 March 2001 on the deliberate release into the environment of genetically modified organisms and repealing Council Directive 90/220/EEC - Commission Declaration. Tekst ove direktive može se naći na internet strani www.eur-lex.europa.eu. 
nadležnog organa članice u kojoj se predlaže oslobađanje genetski modifikovanih organizama. Odredbe se ne primenjuju na genetski modifikovane organizme proizvedene precizno određenim tehnikama genetske modifikacije.

Nakon Direktive iz 2001. godine, 22. septembra 2003. godine doneta je Uredba 1829/2003, ${ }^{14}$ koja uređuje stavljanje u promet genetski modifikovane hrane i stočne hrane, ili proizvoda za ljudsku i stočnu hranu koji sadrže ili potiču od genetski modifikovanih organizama. Kada podnosilac prijave želi da plasira na tržište prehrambeni proizvod koji sadrži genetski modifikovan organizam ili koji potiče od njega, ima sledeće dve mogućnosti:

- ili da se njegova prijava u celosti razmatra unutar delokruga Uredbe br. 1829/2003, primenjujući princip „jedan ključ, jedna vrata“, kako bi dobio dozvolu za namerno uvođenje u okolinu u skladu sa zahtevima opisanim u Direktivi 2001/18/EZ i odobrenje za korišćenje genetski modifikovanih organizama u hrani ili stočnoj hrani po kriterijima zadatim u Uredbi br. 1829/2003;

- ili da se zahtev ili deo zahteva istovremeno podnese na razmatranje po zahtevima Direktive 2001/18/EZ i Uredbe br. $1829 / 2003 .{ }^{15}$

\section{PRAVNI OKVIR ZA GMO U SRBIJI}

Maja 2009. godine donet je Zakon o genetički modifikovanim organizmima, ${ }^{16}$ koji uređuje i zabranjuje genetičke modifikacije na tržištu dostupne potrošačima, i to na sledeći način:

„Ovim zakonom uređuje se postupak za izdavanje odobrenja za upotrebu u zatvorenim sistemima i za namerno uvođenje u životnu sredinu genetički modifikovanih organizama i proizvoda od genetički modifikovanih organizama, uslovi za upotrebu u zatvorenim sistemima i za namerno uvođenje u životnu sredinu genetički modifikovanih organizama, rukovanje, pakovanje i prevoz genetički modifikovanih organizama i proizvoda od genetički modifikovanih organizama, kao i druga pitanja od značaja za genetički modifikovane organizme i proizvode od genetički modifikovanih organizama." Plasiranje proizvoda uređeno je čl. 2. i 3. ovog zakona: „Nijedan modifikovan živi organizam kao ni proizvod od genetički modifikovanog organizma ne može da se stavi u promet, odnosno gaji u komercijalne svrhe na teritoriji Republike Srbije."

14 Regulation (EC) No 1830/2003, traceability and labelling of genetically modified organisms and the traceability of food and feed products produced from genetically modified organisms and amending Directive 2001/18, http://www.food.gov.uk/scotland/regsscotland/regsguidscot/scotgmfoodfeedguide.

15 http://www.gmo.hr/zakonska_regulativa/zakoni_europske_unije .

16 Zakon o genetički modifikovanim organizmima, 29. maj 2009, „Službeni glasnik RS“, br. 41/09. 
"Genetički modifikovan organizam ne smatra se poljoprivredni proizvod biljnog porekla koji količinski sadrži do 0,9\% primesa genetički modifikovanog organizma i primesa poreklom od genetički modifikovanog organizma.

Semenski i reproduktivni materijal ne smatraju se genetički modifikovanim organizmima ukoliko količinski sadrže do $0,1 \%$ primesa genetički modifikovanog organizma i primesa poreklom od genetički modifikovanog organizma."

U 2009. godini, tačnije 7. septembra, u izveštaju broj RB9006 Američkog ministarstva za poljoprivredu (USDA), koji je pripremila Tatjana Maslac, a odobrila Hoa Huynh u ambasadi SAD u Beogradu, ${ }^{17}$ navodi se sledeće:

„Novi srpski zakon o genetički modifikovanim organizmima, koji je stupio na snagu juna 2009. godine, apsolutno zabranjuje uzgoj i prodaju biotehnoloških proizvoda, dok samo u osnovnim crtama reguliše upotrebu GMO u zatvorenim i kontrolisanim uslovima, u eksperimentalne svrhe. Vlada SAD, EU i drugi članovi Svetske trgovinske organizacije izrazili su veliko nezadovoljstvo novim zakonom. Srpski zvaničnici zaduženi za trgovinu prepoznali su opasnost od moguće zabrane pristupanja Srbije Svetskoj trgovinskoj organizaciji i posvećeni su promeni zakona koji zabranjuje genetičke modifikacije. Dobili smo uveravanja od visokih srpskih zvaničnika da će se insistirati na promeni zakona što pre, verovatno već u sledećem zasedanju parlamenta na jesen 2009. godine.

Jula meseca, radno telo Svetske trgovinske organizacije (USTR), koje se sastaje u Ženevi, namerava da srpskoj delegaciji saopšti izuzetno detaljan komentar na ovaj sporni zakon koji zabranjuje genetičke modifikacije u Srbiji.

Američko ministarstvo za poljoprivredu (USDA) pomaže u gradnji kapaciteta Srbije po pitanju biotehnologije u poljoprivredi od 2001. godine. Takođe, USDA/OCBD je trenirala učesnike iz Srbije da kritički procene tehnički i ekonomski aspekt biotehnologije i ubede da se u strategije uvrsti primena biotehnologije.

Rad na promociji GM hrane ne postoji. U Srbiji, štaviše, javno mnjenje je protiv upotrebe GMO-a, što se objašnjava izuzetnom neobaveštenošću o prednostima GMO-a, itd." 18

Uzimajući u obzir detaljan izveštaj Američkog ministarstva za poljoprivredu, vrlo je verovatno da će važeći zakon o GMO biti izmenjen i dopunjen, jer će u protivnom Republika Srbija snositi ozbiljne ekonomske konsekvence. Ostaje da sačekamo najavljene izmene važećeg zakona, koje će verovatno ići

17 http://gain.fas.usda.gov/Recent\%20GAIN\%20Publications/AGRICULTURAL\%20BIOTECHNOLOGY\%20ANNUAL_Belgrade_Serbia_7-9-2009.pdf.

18 Kompletan izveštaj USDA može se pročitati na internet strani http://gain.fas.usda. gov/Recent\%20GAIN\%20Publications/AGRICULTURAL\%20BIOTECHNOLOGY\%20 ANNUAL_Belgrade_Serbia_7-9-2009.pdf. 
u smeru liberalizacije pravnog režima genetski modifikovane hrane na tržištu Republike Srbije, ali da ne prejudiciramo, svakako da će naučna javnost dati svoj sud o istim kada za to bude bilo potrebe.

\section{UTICAJ BIOTEHNOLOŠKIH KORPORACIJA NA KONAČNI ISHOD NAUČNIH REZULTATA}

Budući da je u državnom budžetu na raspolaganju sve manje novca za istraživanja, sve više naučnika u SAD i Evropi zavisi od korporacijskih sponzora, a time i od korporacijskog prihvatanja njihovih istraživanja i rezultata.

Na primer, na vrhunskim britanskim istraživačkim fakultetima, privatno finansiranje čini od 80 do 90 odsto ukupnog istraživačkog budžeta. Naime, oslanjanje na korporacijsko sponzorisanje može imati skrivenu cenu. Stupili smo u eru biotehnološkog imperijalizma. ${ }^{19}$

Na uzorku koji je obuhvatio pet stotina naučnika koji rade u državnim ili u nedavno privatizovanim istraživačkim institutima u Velikoj Britaniji otkriveno je kako je trideset odsto njih bilo pod direktnim uticajem sponzora koji je tražio modifikovanje zaključaka istraživanja. Prema izveštaju objavljenom $\mathrm{u}$ britanskom časopisu Times Higher Education Supplement 2000. godine, ${ }^{20}$ „taj je broj uključivao sedamnaest odsto naučnika od kojih je zatražena promena zaključaka kako bi odgovarali željenom ishodu stranke, deset odsto naučnika od kojih je promena zatražena kako bi dobili daljne ugovore i tri odsto od kojih je promena zaključaka zatražena kako bi se sprečilo njihovo objavljivanje."

Ako je čak trideset odsto naučnika priznalo da se od njih zahtevala promena rezultata, postavlja se pitanje koliko je drugih naučnika, koji su se podredili zahtevu svojih stranaka, bilo previše osramoćeno kada bi iskreno odgovorilo na ovo pitanje. U navedenom časopisu napominje se „kako komercijalizacija naučnih istraživanja preti standardima nepristrasnosti“.

Dr Richard Smith, urednik British Medical Journala, kaže da „sukobi interesa“ koji sponzorišu istraživanja, imaju „veliki uticaj na zaključke“. On upozorava: „Zavaravamo sami sebe ako smatramo da je nauka potpuno nepristrasna. " 21

U SAD su za manje od deset godina, od 1985. do 1995. godine, donacije korporacija porasle sa 850 miliona dolara na 4,25 milijardi dolara. Prema časopisu Atlantic Monthly, „novac sve češće prate i određene obaveze“.22 U visokom obrazovanju korporacije ne samo da sponzorišu sve veći broj istraži-

19 www.well.org.rs.

20 www.timeshighereducation.co.uk.

21 Više informacija i srodnih članaka se može naći na internet adresi www.bmj.com.

22 www.theatlantic.com/food/archive/2009/04/does-genetic-modification-work/16366/. 
vanja - one sve češće diktiraju načine njihovog sprovođenja.“ „Od problema prisilne tajnosti i odlaganja“, piše u članku objavljenom u časopisu Atlantic Monthly, „još je gora mogućnost da iza zatvorenih vrata neki korporacijski sponzori manipulišu radovima pre objavljivanja kako bi poslužili njihovim komercijalnim interesima... Istraživanje sprovedeno u velikim istraživačkim centrima u oblasti inženjeringa otkrilo je kako bi 35 odsto naučnika dopustilo korporacijskim sponzorima da pre objavljivanja uklone informacije iz njihovih radova." 23

Nadalje, mnogi profesori imaju akcije u kompanijama koje sponzorišu njihova istraživanja, ili sede u njihovim odborima, ili se jednostavno oslanjaju na korporaciju za nastavak finansiranja istraživanja.

Čak i fakulteti ulažu u kompanije koje finansiraju fakultetska istraživanja ili imaju od njih koristi. „U istraživanju osam stotina naučnih radova objavljenih u akademskim časopisima, Sheldon Krimsky, profesor javne politike na Univerzitetu Tufts i vodeći autoritet na području sukoba interesa, otkrio je kako je malo više od trećine autora imalo značajan finansijski interes u svojim izveštajima. " 24 Međutim, nijedan od tih radova nije otkrio tu informaciju. Mildred Cho, viša istraživačica iz Centra za biomedicinsku etiku sa Stanforda (Center for Biomedical Ethics), kaže: „Kad imate toliko naučnika u odborima kompanija i toliko njih koji sprovode sponzorisana istraživanja, zapitate se kako se ta istraživanja osmišljavaju? Koja se istraživačka pitanja postavljaju? Koja se ne postavljaju?" 25

Postojanje korporacijskog uticaja na rezultate naučnih istraživanja najbolje će ilustrovati slučaj Univerziteta Berkli u Kaliforniji. Novembra 1998. godine, Univerzitet Berkli je potpisao sporazum sa farmaceutskim gigantom „Novartisom“. Prema odredbama sporazuma, biotehnološka kompanija „Novartis" obezbedila je 25 miliona dolara za istraživanja, namenjenih Odeljenju za biologiju biljaka i mikroba na Univerzitetu.

Istim sporazumom ustanovljeno je pravo prvenstva u korist „Novartisa“ prilikom izdavanja dozvola za oko trećinu otkrića sponzorisanog odeljenja. To uključuje otkrića koja je finansirao „Novartis“, ali i ona koja finansiraju savezni i državni izvori. Sporazumom je takođe predviđeno pravo "Novartisa“ na odlaganje objavljivanja istraživanja čak i do četiri meseca, što omogućava patentiranje datog otkrića, kao i nesmetanu upotrebu informacija koje poseduje. Za kraj ilustracije treba napomenuti da je ovim sporazumom pred-

23 The Kept University, Jennifer Washburn, objavljenom u Atlantic Magazine 2000. godine, u elektronskoj formi se može naći na internet strani www.theatlantic.com/magazine/archive/2000/03/the-kept-university/6629.

24 Combating the Funding Effect in Science: What's Beyond Transparency? Stanford Law \& Policy Review, Vol. XXI, str. 101-123 (2010).

25 Eyal Press and Jennifer Washburn, The Kept University, Atlantic Magazine 2000. 
viđeno i da će „Novartis“ delegirati dva člana, od ukupno pet, u odbor koji odlučuje o trošenju novca za istraživanja. ${ }^{26}$

Istraživanje objavljeno u časopisu Journal of the American Medical Association otkrilo je da su istraživanja lekova protiv raka, koja su finansirale neprofitne grupe, osam puta češće dolazila do nepovoljnih rezultata od istraživanja koja su finansirale farmaceutske kompanije. Takođe se možemo osvrnuti i na slučaj genetski modifikovanog veštačkog zaslađivača. Do 1995. godine, na njemu je sprovedeno oko 165 istraživanja koja su recenzirali drugi stručnjaci. Gotovo su ravnomerno podeljena između onih koja nisu otkrila nikakve probleme i onih koja su dovela u pitanje sigurnost zaslađivača. Istraživanja koja nisu otkrila nikakve neželjene posledice, sto posto je finansirao proizvođač zaslađivača. ${ }^{27}$

\section{UTICAJ GENETSKI MODIFIKOVANIH ORGANIZAMA NA ZDRAVLJE LJUDI I NA ŽIVOTNU SREDINU}

Uticaj genetski modifikovanih organizama na prirodu i na sav živi svet uopšte je višestruk. Genetske modifikacije mogu da:

- sadrže i stvaraju opasne i otrovne supstance,

- izazovu različite i još uvek nepoznate alergijske reakcije,

- smanje hranljivu vrednost namirnice,

- izazovu otpornost bakterija na antibiotike itd.

26 Jennifer Washburn, The Kept University, Atlantic Magazine, 2000.

27 Velika i poznata kompanija „Monsanto“, koja se inače bavi i promocijom i proizvodnjom genetski modifikovane hrane, 1985. godine kupila je „G D Searle“ - farmaceutsku kompaniju koja je imala patent za proizvodnju aspartama. U to je vreme funkciju predsednika „Searlea“ vršio Donald Rumsfeld, osoba koja je poznata javnosti kao ministar odbrane za vreme mandata George W. Busha mlađeg. Rumsfeld je prodajom „Searlea“ „Monsantu“ zaradio oko 12 miliona dolara. „Monsanto“ nije zabrinjavalo što je aspartam u to vreme već bio predmet istraživanja tri različita nezavisna naučnika, koji su utvrdili da aspartam može prouzrokovati tumor mozga. FDA je na osnovu tih istraživanja zabranila upotrebu aspartama, ali Rumsfeld je povukao svoje političke veze kako bi postigao povlačenje zabrane. Oformljena je nova petočlana grupa koja je trebalo da ponovo proceni štetnost aspartama. Kada je postalo jasno da će, sa tri prema dva glasa, aspartam ostati na listi zabranjenih supstanci, čelna osoba FDA Arthur Hayes Hull, koji je potajno radio na ozakonjenju aspartama, u grupu uvodi šestog člana koji glasa u korist aspartama. Pat poziciju od tri prema tri glasa, rešava sam Arthur Hayes Hull, koji tako na kraju svoje farse, svojim glasom odlučuje da se aspartam legalizuje. Aspartam je, uprkos brojnim istraživanjima i upozorenjima savesnih stručnjaka i lekara, do danas ostao legalan, koristi se u više od devet hiljada proizvoda, što dovoljno govori o snazi „Monsanta“ i uticaju koji ta bogata kompanija ima na one koji donose odluke. (Tekst u engleskoj verziji se može naći na http://www.rense.com/general33/legal.htm). 


\subsection{Alergijske (hipersenzitivne) reakcije nastale upotrebom genetski modifikovane hrane}

Genetskim inženjeringom mogu se preneti alergeni iz namirnica sa poznatim alergogenim sposobnostima (kikiriki, orah, školjke i riba) na namirnice za koje se pretpostavlja da su sigurne, pa se tako, na primer, alergen iz brazilskog oraha prenosi u soju kako bi se poboljšao proteinski sadržaj, što je od značaja za ishranu životinja. In vitro i testom kožne probe potvrđeno je da je genetski modifikovana soja reagovala sa IgE osoba koje imaju alergiju na brazilski orah, što znači da bi te osobe reagovale alergijski (možda i fatalno) na soju. ${ }^{28}$

U budućnosti proteini će biti ubacivani u biljke ne samo iz dosadašnjih poznatih izvora alergena (školjke, mlečni proizvodi i koštunjavo voće), već i iz biljaka svih vrsta, bakterija i virusa čija je potencijalna alergogenost retka ili nepoznata.

Mada sve biljke sadrže materije koje su potencijalni alergeni za ljude, genetski modifikovane žitarice su novi varijeteti kod kojih promena genoma žitarica može dovesti do neželjenih promena proteina žitarica, koji postaju jači alergeni. Ozbiljnija ispitivanja alergogenosti genetski modifikovanih biljaka nisu do danas urađena. Uz to, do danas nauci nisu poznati pouzdani načini određivanja da li će određeni protein delovati alergogeno ili ne, osim testova sa serumima uzetih od osoba alergičnih na taj protein.

Pozitivnim propisima mora se regulisati da svaka genetski modifikovana namirnica mora biti deklarisana, kako bi osetljive osobe mogle da je izbegavaju. Ubrzo pošto je genetski modifikovana soja uvedena u Veliku Britaniju, alergije na soju su skočile za 50 odsto.

\subsection{Toksični uticaji genetski modifikovanih namirnica}

Žita koja sadrže toksin Bacillus thurigiensis (Bt) mogu delovati štetno na ljudsko zdravlje. Skoro polovina (44\%) gusenica Lepidoptera, hranjenih u laboratoriji isključivo listovima mlečike na koje je bio nanet polen Bt kukuruza, uginula je za četiri dana. Polen genetski modifikovanog žita može se širiti insektima i vetrom na velike daljine: polen se obično prenosi na daljinu od oko 180 metara, ali ga pčele i vetar mogu preneti i nekoliko desetina kilometara daleko. Širenjem polena jedna od sto biljaka u nekom polju može postati genetski modifikovan hibrid.

Istraživanja ${ }^{29}$ u Velikoj Britaniji pokazala su da se smrtnost insekata povećava u okruženju genetski modifikovanih biljnih kultura; primer su pčele koje su se hranile na poljima repice genetski izmenjene tako da proizvodi pri-

28 Više o alergijskim reakcijama uzrokovanim konzumiranjem genetski modifikovane hrane može se pročitati na internet strani http://hubpages.com/hub/GMO-Food-Allergies.

29 Više o ovoj temi na http://www.grist.org/article/attack-of-the-superweeds/. 
rodan insekticid koji ubija gusenice i insekte koji su se hranili larvama koje su rasle na genetski modifikovanim usevima.

Aminokiselina triptofan u većini zemalja registrovana je kao dijetetski dodatak. Japanska kompanija "Showa Denko“ proizvodila je triptofan upotrebom bakterija stvorenih genetskim inženjeringom i prodavala ga u SAD. Posle nekoliko meseci, kod hiljade ljudi utvrđen je sindrom eozinofilijske mialgije sa neurološkim simptomima. Najmanje 1.500 ljudi je trajno onesposobljeno, a 37 je umrlo. Iako kompanija nije želela saradnju sa stručnjacima američke vlade, dokazano je da je toksični sastojak iz genetski modifikovane bakterije izazvao navedeno oboljenje.

Stvaranje toksina, čak i u minimalnim količinama, može imati dugotrajne posledice na zdravlje ljudi. Akumulacija novih metabolita u gajenim biljkama može povećati mogućnost za pojavu toksičnih rizika. Neke kultivisane biljke kao što su krompir i paradajz i normalno stvaraju visoko toksične hemijske materije u lišću, a genetskom modifikacijom mogu nastati nove ili neočekivane supstance čije toksične koncentracije nisu poznate. U svakom slučaju, ne bi trebalo dozvoliti upotrebu genetski modifikovanih prehrambenih proizvoda bez rigoroznih proba njihove toksičnosti.

\subsection{Rezistencija na antibiotike}

Geni rezistentni na antibiotike koriste se u nekim genetski modifikovanim biljkama kao markeri genetske transformacije. Oni se ubacuju pored željenog gena u biljku radi lakšeg uočavanja osobine koja treba da se nasledi, npr. mogućnost stvaranja insekticida u lišću. Uprkos uveravanjima stručnjaka da geni rezistencije ne mogu izaći iz biljke, česta upotreba ovih marker gena može dovesti do egzacerbacije - pojave rezistencije na antibiotike, tj. smanjivanja efikasnosti antibiotika u budućnosti. Realna je mogućnost da se geni iz biljke „premeste“ $u$ mikroorganizme zemljišta, a kako bakterija lako prihvata gene antibiotske rezistencije, kasnije i u patogene bakterije. Moglo bi se desiti, na primer, da se gen antibiotske rezistencije iz hrane prebaci u bakterije u organima za varenje.

Neke zemlje Evropske unije zauzele su stav da antibiotik rezistentne markere definitivno treba ukloniti iz genetski modifikovanog semena zbog eventualnog rizika po zdravlje. Međutim, i dalje iz većine genetski modifikovanih žitarica u svetu (posebno u SAD) ovi markeri nisu uklonjeni.

\subsection{Kancerogeni efekti GMO-a}

Studijom slučaj-kontrola, ${ }^{30}$ koja je sprovedena u Švedskoj od 1987. do 1990. godine, dokazana je povezanost između upotrebe jednog od najprodavanijeg herbicida u svetu - glifosata i non-Hodžkin limfoma. U 1998. godini,

30 Andre Leu, „Monsanto's Toxic Herbicide Glyphosate: A Review of its Health and Environmental Effects“, http://www.organicconsumers.org/articles/article_5229.cfm. 
preko 112.000 tona glifosata upotrebljeno je u svetu, posebno u Aziji, za zaštitu pirinča. Međutim, u većini zemalja Azije ne postoje nacionalni standardi za rezidualne ostatke glifosata, a monitoring ove hemikalije u namirnicama se ne radi. Do sada su već dokazani brojni toksični efekti glifosata, iako proizvođači tvrde da on nije štetniji za zdravlje od soli ili kafe.

Biohemičar A. Pusztai ${ }^{31}$ je izneo tvrdnju da genetski modifikovan krompir oštećuje imuni sistem pacova i utiče na njihov rast. On je dokazao i intestinalne promene kod pacova hranjenih ovakvim krompirom. Njegova je studija pokazala da se kod pacova koji su hranjeni genetski modifikovanim krompirom pojavio potencijalni rast pretkancerogenih ćelija, oštećeni imuni sistem, delimična atrofija jetre i inhibirani razvoj mozga, jetre i testisa. Kada je vodeći naučnik izneo u javnost svoju zabrinutost, odmah je otpušten sa posla posle 35 godina rada i ućutkan je pretnjama o sudskoj parnici.

Veštački uneti genetski elementi mogu da prokrijumčare i neželjene gene u ćeliju (genom) domaćina, što može dovesti do mutagenih i kancerogenih posledica. Ipak, nisu retke i tvrdnje da se eventualni rizik nakon primene genetske modifikacije ne razlikuje bitno od rizika koji može nastati genetskom manipulacijom biljaka tokom tradicionalnog gajenja. Svinje hranjene genetski modifikovanim kukuruzom na nekoliko farmi na srednjem zapadu SAD razvile su lažnu bremenitost ili sterilitet. Krave hranjene genetski modifikovanim kukuruzom u Nemačkoj misteriozno su uginule. A duplo veći broj pilića je uginuo kada je hranjen genetski modifikovanim kukuruzom u poređenju sa onim hranjenim prirodnim kukuruzom. Danas se stiglo dotle da se ukrštaju geni ribe floander iz polarnih voda sa genima paradajza i jagode da bi novostvorena biljka bila otporna na niže temperature.

\subsection{Mišljenje lekara o genetski modifikovanoj hrani}

Američka akademija za medicinu životne okoline - the American Academy of Environmental Medicine (AAEM) - apelovala je na „doktore da informišu svoje pacijente, medicinsku zajednicu i javnost da izbegavaju genetski modifikovanu hranu gde god je to moguće i da obezbede pacijentima informativnu literaturu $u$ vezi sa genetski modifikovanom hranom i njenim rizikom po zdravlje. “32 Oni su pozvali na uvođenje moratorijuma na genetski modifikovanu hranu, sprovođenje dugoročnih i nezavisnih studija i etiketiranje takve hrane. U ovom izveštaju se tvrdi da je „nekoliko studija sprovedenih

31 Arpad Pusztai, Ph.D., „Genetic engineering - genetechnology is it salvation or curse for the $21^{\text {th }}$ century?", The Brown Journal Article objavljen na internet strani http:// www.freenetpages.co.uk/hp/a.pusztai/.

32 Genetically Modified Foods Position Paper AAEM, (This statement was reviewed and approved by the Executive Committee of the American Academy of Environmental Medicine on May 8, 2009.), submitted by Amy Dean and Jennifer Armstrong. Tekst se može naći na adresi http://www.aaemonline.org/gmopost.html. 
na životinjama indiciralo jedan ozbiljan rizik po zdravlje vezan za konzumiranje genetski modifikovane hrane," uključujući neplodnost, probleme sa imunitetom, ubrzano starenje, poremećaje kod regulacije nivoa insulina i promene na glavnim organima i organima za varenje. Oni su zaključili da „postoji više od jedne uzročne povezanosti genetski modifikovane hrane sa štetnim zdravstvenim poremećajima. Postoji tu jedna uzročnost u smislu kako se ona definiše uz pomoć priznatih naučnih kriterijuma. Čvrstina te veze i konzistentnost između GM hrane i bolesti potvrđena je u nekoliko studija sprovedenim na životinjama. " 33 Sve više doktora preporučuje ishranu bez genetski modifikovane hrane. Dr Amy Dean, specijalista interne medicine u Mičigenu i član AAEM panela, kaže, „ja čvrsto preporučujem pacijentima da jedu isključivo hranu koja nije genetski modifikovana. "34 Dr John Boyles, specijalista za alergije iz države Ohajo, kaže, „pre sam stalno ispitivao ljude na alergiju od soje, ali sada kada je soja genetski modifikovana, to je toliko opasno da stalno govorim ljudima da je nikada ne jedu. ${ }^{\text {" }} 35$

Dr Jennifer Armstrong, predsednik AAEM-a, kaže, „doktori verovatno vide posledice kod njihovih pacijenata, međutim, trebalo bi da znaju kako da postave prava pitanja." Poznati svetski biolog Pushpa M. Bhargava ide korak dalje. Nakon što je proučio više od 600 naučnih časopisa, zaključio je da genetski modifikovani organizmi najviše doprinose naglom pogoršanju zdravlja Amerikanaca. ${ }^{36}$

\section{ZAKLJUČAK - NEKA ETIČKA PITANJA U REGULISANJU UPOTREBE GENETSKI MODIFIKOVANIH ORGANIZAMA}

U javnosti se kao veoma česta tema koja je povezana sa pravima građana i potrošača javlja i pitanje obeležavanja proizvoda koji sadrže genetski modifikovane organizme ili od njih dobijenih proizvoda. Međutim, praksa takvog obeležavanja veoma često je u suprotnosti sa samim osnovama na kojima se obeležavanje traži. U mnogim zemljama je to svedeno na puki natpis da „proizvod sadrži GMO“ ili čak da „proizvod može sadržati GMO“, pri čemu je on često dat sitnim slovima i nalazi se na nepristupačnim mestima na ambalaži. Zahtevi za obeležavanje se zasnivaju na pravu na informisanost i pravu na izbor. Međutim, postojeća praksa obeležavanja omogućava samo vrlo skučen izbor između proizvoda koji sadrže genetski modifikovane organizme i onih koji ga ne sadrže. Spektar različitih odluka koje potrošač može donositi je mnogo širi. Da bi se ostvarile i te mogućnosti, potrebna je potpuna informa-

\footnotetext{
33 Ibid.

34 Ibid.

35 Jeffrey M. Smith, „Doctors warn avoid genetically modified food“, www.responsibletechnology.org.

36 Ibid.
} 
cija o tome o kom se organizmu i kom modifikacionom događaju radi, što bi se moglo postići stavljanjem jedinstvenog identifikacionog koda na ambalažu proizvoda. Sasvim su moguće situacije u kojima bi za nekog potrošača bili prihvatljivi biljni geni u biljkama, ali mu ne bi bili prihvatljivi životinjski geni u njima. Tu je i pitanje gena poreklom iz životinja koje su zabranjene za ishranu nekim verskim propisima - pri postojećim regulativama o obeležavanju, da bi bili sigurni, morali biste izbegavati svu genetski modifikovanu hranu. A u mnogim kulturama humani insulin dobijen iz genetski modifikovane bakterije daleko je prihvatljiviji od svinjskog insulina.

U etička pitanja povezana sa genetski modifikovanim organizmima spadaju i ona koja potpadaju pod etiku životne sredine. Pod tim pojmom najčešće podrazumevamo, u najširem smislu reči, ponašanje koje ne dovodi do narušavanja postojeće biološke raznovrsnosti. Gubitak svakog segmenta biološke raznovrsnosti umanjuje potencijal živog sveta, a samim tim i ljudske vrste, da se prilagodi promenljivoj, odnosno menjajućoj životnoj sredini. 